\title{
The development of human resources in the University of Dili, Timor-Leste (A rector's policy study)
}

\author{
Horacio da Costa Guterres Cabral ${ }^{1}$, Ajis SA Djaha ${ }^{2}$, Nursalam Nursalam ${ }^{3}$ \\ Master of Administrative Science, University of Nusa Cendana \\ icless.unc@gmail.com
}

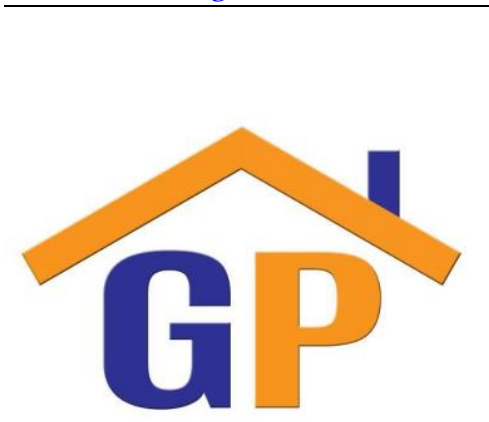

Article History

Received on 23 January 2020

$1^{\text {st }}$ Revision on 1 February 2020

$2^{\text {nd }}$ Revision on 7 February 2020

$3^{\text {rd }}$ Revision on 14 February 2020

Accepted on 2 March 2020

\begin{abstract}
Purpose: This research aims to obtain a description of the policy of developing human resource educators at the University of Dili in accordance with applicable academic regulations.
\end{abstract}

Research methodology: The method used in this research was a descriptive qualitative method. Six respondents were determined as research samples. The research instruments for this study were interview guides, notebooks, recording devices, test books and researchers. Data collection was done through interview method and the data was analyzed by referring to Miles and Huberman's Intractive model framework.

Results: there are some efforts to develop the human resources of educators in universities such as sending of teaching staff to continue their education and various policies that enable the development of educators' human resources. Some factors that influence the development of human resource educators in universities are the organizational structure, organizational policies, allocation of funds, the level of educators' education and the participation of educators in support for the development of human resources

Limitations: this research only discusses the development of educators as human resources at the University of Dili and various factors that influence it.

Contribution: This research was conducted to answer problems related to the management of development for educators as human resources at the University of Dili and what factors influence the development of teaching human resources at the University of Dili Timor-Leste

Keywords: Development, Human resource, Educator

How to cite: Horacio, D. C. G. C., Djaha, A.S.D., \& Nursalam, N. (2019). The development of human resources in the University of Dili, Timor-Leste (A rector`s policy study). Annals of Management and Organization Research, 1(1), 1-7.

\section{Introduction}

The university is one of the educational organizations that can be regarded as a forum to achieve national development goals. The success of educational objectives at the university depends on the human resources that run the university. Human resources in university include the Rector, college students, lecturers, administrative staff, and other education personnel. When the human resources they have are getting better, the quality of human beings produced is also getting better including the development of human resources at the university.

The University of Dili (UNDIL) is located in Dili, the capital of the Democratic Republic of Timor Leste (NRDTL). It was established on May 20, 2002. The University of Dili was once an Economic Academy (STIE) which was established in 1998. After referendum in 1999, the name of this tertiary educational institution was changed and translated into Portuguese into the Instituto Superior Economist Gestao (ISEG). The University of Dili realizes that this institution is one of the main 
supporters of the national development of RDTL in all fields of State development, especially human resource development through higher education programs. The University of Dili (UNDIL) has an academic profile, is independent, collaborates and cares about social and economic inequalities by adhering to the motto "campus of struggle and devotion"

The preliminary research at the University of Dili found several problems. In April 2006 a political and military crisis in Timor Leste affected the activities of the University of Dili. As a consequence of the crisis, the university became a victim where all the facilities and important documents disappeared.. The political crisis that occurred in 2006 has reduced human resources, for the University of Dili, and also reduced the quality of education at the University of Dili.

The credentials have been passed and UNDIL received recognition from and Culture on July 31, 2008 with the status of a trial accreditation. UNDIL recognized and accepted these results as a first step and milestone in the struggle to make UNDIL have the quality based on its vision, mission and goals. The permanent lecturer staff who teach at the University of Dili are bachelors and masters holders. The electronic management information system (SIM) of the faculties is not yet electronic, due to the limited quality of human resources (HR). The administration services are not yet optimal for students and there is no database of collaboration between their departement.

Such a variety of problems has pushed the University of Dili to improve the quality of education by improving the quality of human resources. The researcher believes that the problem of human resources will cause a gap between targets and the reality in education. Therefore, the researcher raised the title of this paper: "The development of human resources in the university of dili, Timor-Leste".

\section{Literature review}

\subsection{Human resource management}

Human Resources are resources sourced from human and must be built or developed (Zainun, 1989: 92). The most important element among other resources in an organization both in government and private organization is human because it plays a role as the main driver in running the wheels of the organization and in all its aspects human plays a very decisive role. In order to realize what is desired by an agency, it is necessary to have a tool to manage and measure these people, namely management which is often referred to as Human Resource Management (HRM) or more known as Personnel Management.

According to Siagian (1995: 47), Human Resource Management is the art and science of planning, organizing, compiling, directing and supervising the resources that have been determined. Meanwhile, according to Handoko (2001: 138), the understanding of human resource management is the withdrawal, selection, placement, development, use and maintenance of human resources to achieve goals, both individual goals and organizational goals.

From the explanation above, it can be concluded that human resource management is management related to humans, both as individuals and as groups that play a role in the activities of an organization. Or it can be said that human resource management focuses on ways to measure employees such as procurement of labor, selection, development, maintenance and use of human resources. Staffing and human resource management are very important for the organization in order to manage and utilize employees so that it can improve performance to achieve organizational goals.

\subsection{The development of human resources}

The development of apparatus resources in an organization is an effort to improve technical, theoretical, conceptual and moral abilities of employees in accordance with the needs of the job or position through education and training (Hasibuan, 1994:76). Development is a systematic process of changing the behavior of employees / apparatus in a direction in order to improve organizational goals. Human resource development is important because it is a method used by organizations to maintain public employees in the organization and at the same time improve the expertise of employees to be able to increase their productivity (Sulistiani and Rosidah, 2003). Human resource development is a process of activities that must be carried out by the organization to increase knowledge, abilities, and skills that are available to meet the demands of the work. (Sihotang, 2007: 206). The development goals include:

- Improving performance, namely updating the expertise of employees in line with technological advancements 
- Reducing learning time for new employees so they can immediately carry out their duties properly

- Helping solve operational problems in the institution

- Preparing employees for promotion in the institution

- Meeting the growth needs of personal learning

(Simamora, 1996: 47)

\subsection{Factors that influence human resource development}

According to Notoatmodjo (2009: 11-12) the implementation of human resource development needs to consider various factors including:

- Internal Factors

Internal factors include the entire life of the organization that can be controlled by both leadership and members of the organization concerned, these factors are:

- Vision as a dream, ideals, or hopes to be achieved by the organization

- Mission

- Purpose

- Strategies for achieving goals

- Nature and type of activity

- The type of technology used

- External factors

An organization is in a certain environment, and can't be separated from the influence of the environment in which the organization is located. In order for the organization to carry out its vision, mission and objectives, it must take into account environmental factors or external factors of the organization. The external factors include:

- Government policy

- Socio-cultural community

- Lean or little organization

- Network organization

- Many organizations are filled with professional positions

- Various organizations

\section{Research methodology}

\section{- $\quad$ Types of research}

This research is descriptive with qualitative methods. This method is called a qualitative method because the research data are interview answers and various literatures.

- $\quad$ Population and Samples

In this study quantitative samples of data sources were determined by purposive and snowball sampling. The sample is temporary and will develop later after research in the field.

- $\quad$ Techniques and Data Sources

The data for this study include secondary and primary data. Data collection is done through interviews and documentation.

- $\quad$ Data analysis technique

Data analysis is done by reducing data and then conclusions are drawn. For tis reason, Interactive Miles and Huberman Models (1992: 20) are used to analyze research data.

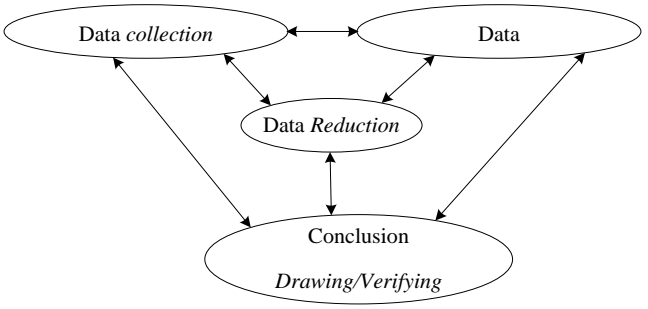

Interactive Miles and Huberman Models 


\section{Results and discussions}

The development of educators' human resources at the University of Dili is still very necessary because it turns out that the results of the assessment indicate that there are still many shortcomings and weaknesses that need to be corrected, especially in the fields of knowledge, abilities, and skills that are not in line with the University's target expectations.

\subsection{The quality of human resource development}

Regarding the quality of human resource development at the University of Dili, the Rector of the University of Dili stated as follows:

"The quality policies of developing Human Resources at Undil are all carried out in accordance with the decisions of the results of the senate meeting, therefore we always try to improve the quality of human resources, to manage an adequate administration system to meet the needs of students every year, especially sending lecturers available to continue education at a higher level in order to improve the outcomes of graduates from Undil. In addition, Undil will also develop lecturers through training, exercises, comparative studies, research, seminars, scientific discussions, and guidance for junior lecturers by senior lecturers. And guidance for junior lecturers at Undil is handled by experienced lecturers from the University of Nusa Cendana, and UNIKA Kupang". (Source: interview with Dr. Jose Agustinho da Costa Pereira Belo, MM on 7 October 2019 in the Undil campus workspace)

According to the assistant rector I of the Dili University,

"The quality of our human resources is currently inadequate, but in the last 3 years the University of Dili has begun to improve its quality by sending several lecturers to continue their masters and doctoral education". (Source: Interview with Francisco M. da Silva LCG, MBA dated. 07 October 2019 on the University of Dili campus).

Meanwhile, according to the Dean of Economic Factors,

"In terms of the quality of the human resources of educators in the Dili University it is already better than in previous years, but we must look for better quality. And the policy of Undil is now prioritized to recruit new lecturers with Masters and Doctoral degrees in accordance with the needs of the faculty, at least lecturers who teach at the University must have Masters and Doctoral degrees. We judge that the global standard of Undil lecturers is sufficient to meet the qualifications. Because seen from each faculty there are already a number of lecturers who hold masters and doctoral degrees either permanent lecturers or part time lecturers"(Source: interview Hernandi S. do Carmo M. ACE On October 7, 2019 on the Undil campus).

From the interviews with the three officials mentioned above, it can be concluded that the quality of human resources at the University of Dili has not met the standards as expected, but currently the University is trying to improve the quality of teaching staff by sending several lecturers to continue their education at masters and doctoral programs in order to improve their individual abilities that will be utilized by University of Dili.

According to Notoatmodjo (1992: 11), the scope of the development of the quality of human resources in an organization includes three main interrelated activities namely:

- Human resource planning

- Education and training

- Human Resource Management

The conclusion is that the development of the quality of human resources is the management or use of human resources in carrying out the wheels of the organization in accordance with the desired organizational performance, with due regard to the level of education, skills, discipline, work environment, relationships between personnel, culture, and management within the organization. Then, to answer the problem of educator human resources at the University of Dili is to pay attention to their abilities and capabilities with training and efforts that support the improvement of the quality of these educators.

\subsection{Various human resource development policies for educators at the University of Dili}

According to the Chairperson of the University of Dili Human Resources,

"Our Human Resource development program for educators at the University of Dili has a policy that is more focused on how the University can improve the ability of individual lecturers, through sending lecturers to continue their education at masters and doctoral programs. In addition, the University of Dili 
provides facilities such as a library with books, a Computer Laboratory equipped with internet, and a health laboratory" (Source: interview with Abel da Costa Pereira, SE. MPA. October 7, 2019 at the Undil campus).

Meanwhile, according to the Dean of the faculty of public health (FKM), "The development policy of educating human resources and the provision of facilities and infrastructure at the Dili University is a joint commitment decided through a university senate meeting, which must be carried out to face future challenges with the argument that in the future, Dili University will no longer teach human resources from Other universities, but it has to be independent in matters related to lectures at the University of Dili, because currently facilities such as our buildings are still dependent on the government "(Source: interview with Ivo da Costa, Soares ST dated 09 October 2019 at the UNDIL Campus).

Based on the interviews of the two officials mentioned above, it can be concluded that the University of Dili in 2010 sent 7 (seven) permanent lecturers to study their masters and doctoral programs, to improve their academic abilities, professionalism, expertise and competitive abilities in accordance with the discipline they have been engaged in and will return to serve at UNDIL to prepare the quality and quantity of future generations of Timor Leste and in order to produce graduates who can master science and technology.

The real effort made by the university to increase the human resources of educators is to send a number of educators to continue their education to masters and doctoral levels. Based on the available data, the number of educators to continue their masters and doctoral programs is as follows.

Table 1

Delivery for the first phase of the 2007-2009 academic year (Masters program)

\begin{tabular}{|c|l|l|l|}
\hline No & \multicolumn{1}{|c|}{ Name } & \multicolumn{1}{|c|}{$\begin{array}{c}\text { From the } \\
\text { Faculty }\end{array}$} & \multicolumn{1}{c|}{ Study in university } \\
\hline 1 & Estevao X. Belo, SE. MM. & The economy & Univ. Gajayana Malang \\
\hline 2 & Jose Agustino Belo, Sip.MM & ISH & Univ. Gajayana Malang \\
\hline 3 & Antonio CC Machado, SPd.MM & FKIP & Univ. Gajayana Malang \\
\hline 4 & Yulita Meledai, SE.MM & The economy & Univ. Udayana Bali \\
\hline 5 & Dra. Sudarmin, M.Acc. & The economy & UGM \\
\hline
\end{tabular}

Source: Academic Section UNDIL 2012

Table 2

Delivery of the second phase of masters and doctoral programs for the 2009/2010 academic year

\begin{tabular}{|c|l|l|l|l|}
\hline No & \multicolumn{1}{|c|}{ Name } & Faculty & Study program & Study in university \\
\hline 1 & Crispinn da C. Pereira, SE & $\begin{array}{l}\text { The } \\
\text { economy }\end{array}$ & M. SP (S2) & UNS Solo, Indonesia \\
\hline 2 & Ivo Da Costa ST Ling & FKM & M. Kes./S2 & UGM, Indonesia \\
\hline 3 & Cosme Alberto, Sip & ISH & M.Fisip./S2 & UGM, Indonesia \\
\hline 4 & AlaricoT. Mendonca, SH & Law & M. Law / S2 & $\begin{array}{l}\text { UNDANA Kupang } \\
\text { Indonesia }\end{array}$ \\
\hline 5 & Antonio C. Cabral, SPd. & FKIP & M. Matika / S2 & $\begin{array}{l}\text { Unv.Brawijaya Malang } \\
\text { Indonesia }\end{array}$ \\
\hline 6 & Carlus T. Buavid, M.Kes. & FKM & DoktorKes./S3 & Nova Lisboa Portugal \\
\hline
\end{tabular}




\begin{tabular}{|c|l|l|l|l|}
\hline 7 & Edegar C. Savio, SE.MA & ISH & D /tor S3 & $\begin{array}{l}\text { len University } \\
\text { Netherlandas }\end{array}$ \\
\hline
\end{tabular}

Source: Academic UNDILYear 2012 ( interview with Vice Rector I Francisco M. da Silva LCG.MBA . On October 7 , 2019 in the Undil campus workspace).

Table 3

Delivery stage three of masters program for the academic year 2014- 2017

\begin{tabular}{|c|l|l|l|}
\hline No & \multicolumn{1}{|c|}{ Name } & \multicolumn{1}{|c|}{$\begin{array}{c}\text { From the } \\
\text { Faculty }\end{array}$} & Kuli ah at the University \\
\hline 1 & Hugo Lourenco da Costa & ISH & UNDANA Kupang \\
\hline 2 & Xisto Gonxalve & ISH & UNDANA Kupang \\
\hline 3 & Cesaltina Angela Soares & ISH & UNDANA Kupang \\
\hline 4 & Imakulada Soares Cabral & ISH & Aveiro Portugal \\
\hline 6 & Antoneta Kuara, Dip., L.Ed & FKIP & UNDANA Kupang \\
\hline 7 & Emilia dos Santos, S.Pd., M.Pd & FKIP & UNDANA Kupang \\
\hline
\end{tabular}

Based on the data above, the efforts of developing university human resource educators are good enough, as seen from the large number of lecturers sent to continue their education. It can be assumed that in the future the university will be able to achieve the desired quality target of human resources. However, the process must be accompanied by other things support the development of the skills of educators.

Factors affecting the development of Human Resources educators at the University of Dili

Based on interviews with several university officials there are several factors that influence the development of human resources at the University of Dili, including:

- university organizational structure

- university policy regarding the development of educator resources

- allocation of funds for the development of teacher skills

- education level of educators

- the involvement of educators to support efforts to develop human resources at the University of Dili

\section{Conclusion}

From the results of research and analysis, it can be concluded that there are efforts to develop human resources for education. From the results of interviews with key informants working at the University of Dili about the development of human resources so far have not met the standards expected by the University. However, there are efforts to improve the development of educators' human resources at the University of Dili such as sending lecturers to various universities abroad, increase their academic knowledge in order to develop the human resource of educators at the University of Dili, in the future with regard to the short-term, medium-term and long-term policies determined by the University based on Senate decisions. In addition, Dili University collaborates with Undana Kupang University and Kupang Catholic University to conduct training for senior and junior lecturers to improve their individual abilities so that they can carry out good quality activities based on students' needs. In addition, the university must reform the administration system at the University to support college activities.

While the factors that influence the development of human resource educators at the University of Dili can be seen from the overall leadership at the University of Dili starting from the Chancellor, Vice Chancellors I, II, III and deans of each faculty, which then spread to the department, all of whom can work and support each other to improve the development of human resources at the University of Dili, in accordance with the responsibilities that have been determined based on existing policies. In addition, several things such as delegation of authority in the organization, involvement of educators 
and adequate allocation of funds are other factors that must be taken into consideration to support the growth of the quality of existing human resources. With the efforts to improve the quality of human resources, educators believe that universities can achieve the desired quality target of human resources.

\section{Limitation and future research directions}

This study only examines the development of human resource educators at the University of Dili and various factors that influence it. In the future other researchers can develop this research by using other variables that can affect the human resources of educators. The researcher also recommends using a quantitative method so that other perspectives on human resource development at universities or other institutions can be obtained.

\section{References}

Handoko, T. H. (2001). Manajemen personalia dan sumber daya manusia BPFE UGM, Yogyakarta. Hasibuan, Malayu. (1994). Manajemen sumber daya manusia. Jakarta: Haji Masagung.

Miles, B. Mathew dan Michael Huberman. (1992). Analisis data kualitatif buku sumber tentang metodemetode baru. Jakarta:UIP.

Notoatmodjo, Soekidjo. (1992). Pengembangan sumber daya manusia (edisi revisi). Jakarta: Rineka Cipta.

Notoatmodjo. (2009). Pengembangan sumber daya manusia. Jakarta: PT. RINEKA.

Siagian, Sondang P. (1995). Manajemen sumber daya manusia. Jakarta: Bumi Aksara.

Sihotang. (2007). Manajemen sumber daya manusia. Jakarta: PT. Pradnya Paramita.

Simamora, Henry. (1996). Manajemen sumber daya manusia, Yogyakarta: SKPN.

Sulistiani, Ambar Teguh dan Rosidah. (2003). Manajemen sumber daya manusia, Yogyakarta: SKPN. www.undil.tl. Istoria Universidade Dili. undil.tl/perfile-undil.html. diakses pada 20 Januari 2007.

Zainum, Buchari. (1989). Manajemen dan motivasi. Edisi Revisi. Jakarta: Balai Aksara. 